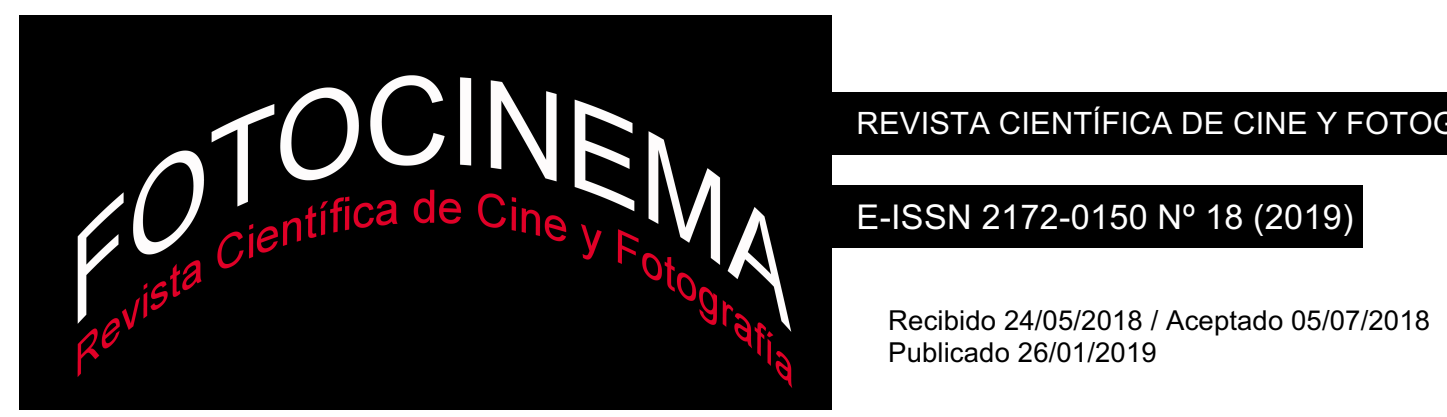

\title{
Rojo amanecer: el problema de la imagen de Tlatelolco 1968
}

\section{Rojo amanecer: the image problem of Tlatelolco 1968}

\author{
Carlos Belmonte Grey \\ Université d'Evry Val-d 'Essonne/ Universidad de Guadalajara-CUNorte \\ carlosbelmontegrey@hotmail.com \\ ORC ID. 0000-0001-9676-423X
}

\section{Resumen:}

Este texto plantea una discusión en torno a la carencia de imágenes vehiculadoras de la memoria histórica de Tlatelolco 1968. A 50 años del 2 de octubre de 1968 en México no existen reconstrucciones iconográficas identitarias de un evento considerado coyuntural para el Estado moderno mexicano, como sí lo hay del considerado acontecimiento fundador del México moderno -la revolución mexicana de 1910- o del esplendor de la modernización -el cine del periodo de Miguel Alemán-. A partir de la película Rojo amanecer realizada por Jorge Fons y escrita por Xavier Robles y Guadalupe Ortega se puede problematizar este espectro visual y al mismo tiempo ubicarla como la ficción que aporta las imágenes referentes del acontecimiento, mas no se trata de imágenes cuya peso simbólico remite a una memoria inmediata ni formen parte de un discurso visual de la noche de octubre. Dicho espectro y carencia de vehiculación se debe, creemos, a la descomposición de la memoria de la tercera generación después del acontecimiento, un fenómeno que Marianne Hirsch ha llamado la posmemoria, una noción analítica para explicar el proceso de transmisión intra y transgeneracional y las barreras entre ellas.

\begin{abstract}
:
This text raises a discussion about the lack of vehicular images of the historical memory of the 1968 massacre at Tlatelolco. Fifty years after the massacre occurring on October 2, 1968 in Mexico City, there have been no reconstructions of identity-shaping visuals around this event, considered a turning point for the modern Mexican State. This is in contrast to the abundant imagery created around the Mexican Revolution, the founding event of Modern Mexico, or the splendor of modernization, handily characterized by the film industry during the Miguel Aleman presidency. Using as a case study the film Rojo Amanecer by Jorge Fons, written by Xavier Robles and Guadalupe Ortega, we can problematize this visual language as well as contextualize it as a fiction that, eventually, would contribute to the referential images of the event, while at once recognizing the images' symbolic weight does not refer to immediate memory nor do they form part of a visual discourse of that October night. We believe this absence is due to the breakdown of the memory of the third generation after the event, a phenomenon that Marianne Hirsch has called postmemory, an analytical concept used to explain the intra- and transgenerational processes and barriers.
\end{abstract}

\section{Palabras clave:}

Tlatelolco 1968; cine político mexicano; memoria y monumentalización; posmemoria; imagen espectro; Rojo amanecer.

Keywords:

Tlatelolco 1968; political mexican cinema; memory and monumentalisation; postmemory; missing image; Rojo amanecer (Red Dawn). 


\section{Introducción'}

En 1991 comenzó su recorrido comercial la primera ficción sobre los acontecimientos del 2 de octubre de 1968 en la plaza de las Tres Culturas de Tlatelolco. La película se proyectó al momento en que la generación que había vivido en su adolescencia la matanza educaba a sus propios hijos, a quienes protegía de sufrir un choque político y social semejante. En ese momento, entonces, la película provocó debates entre los espectadores conocedores del suceso. Rojo amanecer se convirtió en la película referencia de la matanza de Tlatelolco. Por eso, para conmemorar el 50 aniversario del 68 mexicano la cinta fue recuperada para los eventos públicos y universitarios. Sus escritores, Xavier Robles y Guadalupe Ortega, acompañaron algunos de éstos (se puede citar la proyección-debate en la Universidad de Guadalajara Campus Norte) ${ }^{2}$ para animar los debates. Los autores se dieron cuenta que del suceso se sabía poco y que no había, entre los espectadores jóvenes estudiantes, referencias visuales y auditivas (Ortega y Robles, 2018). Contrario a lo que sucede con la literatura, los nombres de algunos cronistas y ensayistas como Elena Poniatowska, Carlos Monsiváis y Paco Taibo II están vinculados al 68 y sí son constantemente citados. 3

Rojo Amanecer fue una película dirigida por Jorge Fons en 1989, coproducida por Héctor Bonilla y Valentín Trujillo. La cinta de Fons ha sido abordada principalmente desde dos frentes: por una parte, se le reconoce ser la primera ficción cinematográfica de la represión contra los estudiantes el 2 de octubre de 1968 en Tlatelolco y por tanto, parte de los discursos que dan cuenta de las catástrofes políticas latinoamericanas; y por el otro, desde la importancia simbólica de los personajes (interpretados por los actores María Rojo, Héctor Bonilla, Demián Bichir, entre otros), notablemente en la composición de la familia conformada por tres generaciones y en la figura del niño como único

\footnotetext{
${ }^{1}$ Las ideas centrales de este artículo fueron presentadas y debatidas en los coloquios : Entre le summer of love et le Cordobazo, ENS Paris-Saclay, 19 janvier 2018 ; y el 8vo Foro Internacional de Análisis Cinematográfico: Cine, violencias y democracia, Cecut-Ibero-UABC, Tijuana, septiembre 2018.

${ }^{2}$ Jornada "El cine político de México. Proyección de Rojo amanecer", UdeG-Cunorte, 8 de marzo 2018.

3 Para un recorrido analítico de la literatura generada se puede consultar: Jurado, D. (2017). Catastrophe et récit. La représentation littéraire et cinématographique du "terrorisme d'État" en Argentine, au Chili et au Mexique. Paris, Francia: Tesis Doctoral, Université Sorbonne, pp. 141146.
} 
sobreviviente y testigo transmisor para no olvidar la matanza. A partir de estos dos aspectos, con algunas pequeñas variantes más bien localizadas en el acercamiento a veces forzado a la teoría cinematográfica, Rojo amanecer se ha convertido en la cinta icónica del suceso. 4

Este texto no se preocupa directamente por analizar la película ni por la reconstrucción de la historia o la actualización de la historiografía del acontecimiento. Se trata de un planteamiento que problematiza la carencia de imágenes vehiculadoras de la memoria histórica del acontecimiento. A 50 años del “2 de octubre de 1968 en México” no existen reconstrucciones iconográficas identitarias de un evento considerado coyuntural para el Estado moderno mexicano, como sí lo hay del considerado acontecimiento fundador del México moderno -la revolución mexicana de 1910- o del esplendor de la modernización -el cine del periodo de Miguel Alemán-. Para ser más precisos, consideramos que no hay imágenes recuperadas del acontecimiento que hayan transitado generacionalmente y se hayan convertido en referentes visuales y discursivos del 68 mexicano. Miguel Errazu se ha referido a este fenómeno -aunque él lo hace a partir del cine experimental en específico del conjunto de cortometrajes reunidos bajo el título Hacer memoria: archivos del 68- como una presencia espectral o un fantasma que evidencia la dificultad de figurar y "hacer aparecer, en el campo de lo sensible, una cierta inteligibilidad de las formas que se refieran a la precariedad de la vida, a la violencia y a las formas de resistencia...” (Errazu, 2018, pp. 228 y 232).

A partir de Rojo amanecer se puede problematizar este espectro visual y al mismo tiempo, aunque parezca paradójico, ubicarla como la ficción que aporta las imágenes referentes -ficticias- del acontecimiento. La película se ha vuelto la marca identificadora de la matanza. Se tiene que precisar, las imágenes existen, principalmente las captadas por los estudiantes del Centro Universitario de Estudios Cinematográficos CUEC y montadas en documentales. Sin embargo, estas no han sido un recurso de transtextualidad (Ebbrecht--Hartmann, 2015, p. 35) ni han caminado por generaciones. Creemos que se trata del asunto de

\footnotetext{
4 Ver por ejemplo: Velazco, S. (2005). Rojo amanecer y La ley de Herodes, cine político de la transición mexicana. Hispanic research journal, 6 (1), 67-80. Rojo, J.J. (2010). La memoria como espectro en Rojo amanecer de Jorge Fons. Arizona Journal of Hispanic Cultural Studies, 14, 4964. Vázquez Mantecón, A. (1998). No se olvida... rojo amanecer. Estudios Interdisciplinarios de América Latina y el Caribe, 9 (1), 141-144.
} 
descomposición de la tercera generación después del acontecimiento, un fenómeno que Marianne Hirsch ha llamado la posmemoria y cuyo método recupera las fuentes familiares con sus recuerdos personales -álbumes de fotosy otros cuerpos de imágenes dejados por los propios testigos pero que han vivido una intensa mediatización tanto en redes de la memoria familiar, la memoria cultural y la institucionalización y monumentalización de la memoria. Cabe aclarar que este esquema de la posmemoria consiste más en ser una noción analítica para explicar el proceso de transmisión intra y transgeneracional que una metodología de investigación (Hirsch, 2008, pp. 106 y 114-115).

Este documento se divide en dos partes: una primera se centra en una breve historia de la película, escritura, censura, proyección y, por supuesto, el dispositivo. La segunda insiste en el problema de la memoria del acontecimiento, de su representación y de la ausencia de archivos montados por el efecto de ficciones mediatizadas, como sucedió con, por ejemplo, la Shoah en La lista de Schindler (Schindler's List, Steven Spielberg, 1993). Se plantea, pues, el conflicto de la selección de imágenes que se podrían utilizar en archivos de memoria de la cultura de masas (cine y televisión) (Bratu, 1996). Por otra parte, este texto sigue de cerca la entrevista realizada a Xavier Robles y Guadalupe Ortega, argumentistas y guionistas de la película; la entrevista se organizó para que pudiéramos observar su interpretación en 1989 del 1968 vivido por ellos y el 2018 de sus expectativas.

\section{El film, Rojo amanecer}

El 2 octubre de 1968 hubo un mitin en la Plaza de las Tres Culturas ubicada en el barrio de Tlatelolco del entonces Distrito Federal (hoy Ciudad de México). Los estudiantes de la ciudad llevaban dos meses manifestándose contra la represión gubernamental entre cuyas consecuencias estaba la ocupación de Ciudad Universitaria (UNAM) y del Instituto Politécnico Nacional (IPN). Los estudiantes habían conseguido que algunos sectores de trabajadores y de la población se les unieran y apoyaran llamando a huelgas y mítines5. México era la sede de los Juegos Olímpicos a celebrarse desde el 12 de octubre de ese año. Por eso, según 
la versión más difundida, el presidente Gustavo Díaz Ordaz ordenó lanzar un escarmiento severo contra los manifestantes y someterlos al orden institucional. El 2 octubre, el Batallón Olimpia -grupo paramilitar del gobierno- y el ejército mexicano reprimieron el mitin disparando contra los manifestantes, persiguiéndolos hasta dentro de las casas y desapareciendo y matando a varios (se calculan 200 muertos en cifras oficiales).

Del evento, los estudiantes del CUEC montaron el documental El grito (Leobardo López Aretche, 1969) pero fue 22 años más tarde cuando se realizó la primera ficción, Rojo amanecer. La cinta fue escrita por Xavier Robles tras haber entrado a la industria del cine gracias a la invitación de Tomás Pérez Turrent para coescribir Las poquianchis (Felipe Cazals, 1976). Empezó, desde entonces, a trabajar en la escritura de otros libros cinematográficos para Felipe Cazals como Bajo la metralla (1983) y Los motivos de luz (1985). Estas películas surgieron de su experiencia, y de la de Guadalupe Ortega, como reporteros, militantes del movimiento estudiantil -aunque no como estudiantes pues Robles dejó la escuela en segundo de secundaria, sino como miembros de otras agrupaciones- y afiliados a las guerrillas urbanas. Su incursión desde 1969 en los movimientos de resistencia urbanos y la posterior represión y desaparición de sus compañeros les obligó a huir de su departamento de Tlatelolco con su hija recién nacida y pasar un tiempo en la clandestinidad. Esta etapa perfiló sus historias rechazando el uso de las armas y la existencia de los movimientos violentos porque eran, asesta Robles, "muy tontamente románticos... llenos de mucho aventurerismo" pero, completa Guadalupe Ortega, "parte de un proceso histórico" (Ortega y Robles, 2018).

El libro cinematográfico - como Robles prefiere llamar al argumento y guion de las películas- surgió tras una convocatoria hecha por el Banco de Guiones, ligado a la Sociedad General de Escritores y a su vez al Sindicato de Trabajadores de la Producción Cinematográfica, para escribir argumentos a concurso. El ganador o ganadores serían apoyados para la escritura de la obra. Bengalas en el cielo título original de la película de Rojo amanecer- fue seleccionado unánimemente. Sin embargo, rápidamente se enfrentaron al problema de conseguir un productor que pudiera hacer frente a la previsible censura del proyecto. Un primer intento se dio cuando la Secretaria de Gobernación del presidente Carlos Salinas de 
Gortari hizo un llamado a la libertad de expresión en el cine, entonces un productor cuestionó si esta libertad se extendería para filmar Bengalas, la respuesta del gobierno fue "con el ejército no se metan" (Ortega y Robles, 2018). La suerte cambió con María Rojo quien se interesó por el proyecto, contactó a Jorge Fons para la dirección y a Héctor Bonilla para la producción, éste quería demostrar que era capaz de actuar fuera de las telenovelas y decidió producir la cinta. El dinero se terminó y tuvieron que buscar más recursos para terminar el rodaje y costear la postproducción, en ese momento se incorpora Valentín Trujillo de coproductor pero exige que se cambie el nombre porque lo consideraba "demasiado poético" y él prefería “Tlatelolco sangriento", concluyeron en negociar un término medio, entre lo poético de Robles y lo comercial de Trujillo, Rojo amanecer (Ortega y Robles, 2018).

Vino entonces la etapa de la exhibición. La cinta se terminó de rodar en 1989 pero tuvo que esperar ocho meses para obtener la autorización de exhibición en salas. La Dirección de Cinematografía estaba tardando la autorización a fin de -opina Robles- "enlatarla" (término usado para referirse a películas que no salían de las latas de película y se quedaban en las bodegas) como había sucedido con La sombra del caudillo (Julio Bracho, 1960), incluso Robles y Ortega consideran que el gobierno prefirió desenlatar la película de Bracho para retardar la autorización de Rojo amanecer. Para desenlatarla el equipo de la película montó una demanda desde la Sociedad de Autores contra la Secretaria de Gobernación arguyendo censura. La prensa, los actores y directores secundaron y presionaron a Gobernación para que finalmente autorizara la salida en salas aunque con seis cortes que significaron dos minutos y 20 segundos de tiempo de pantalla, todas las escenas estaban relacionadas con la aparición del ejército (Robles y Ortega, 1995, pp. 16-17). En 1991 la cinta ganó 11 Arieles -premios de la Academia Mexicana de Artes y Ciencias Cinematográficas- incluyendo Mejor Película, Director, Actores, Argumento y Guion.

Dos años de vida feliz tuvo el recorrido de Rojo amanecer en México. Las proyecciones, recuerdan Robles y Ortega, provocaban disputas entre el público: de un lado quienes reconocían la represión del gobierno y del otro quienes consideraban exageraciones o mentiras. Los escritores calculan que la cinta tuvo 10 millones de espectadores en México, mientras que en el extranjero no tienen 
cifras porque la película nunca tuvo corrida comercial fuera del país (Ortega y Robles, 2018). Después de estos dos años la cinta se perdió y esperó su salida en televisión ya sin el corte de los dos minutos. La película fue comprada, dentro de un paquete, por Claro Video, compañía del mexicano Carlos Slim, y desde entonces ha estado enlatada -aunque el término en sentido estricto ya no corresponde- de las proyecciones oficiales.

Rojo amanecer es la historia de una familia (abuelo -antiguo general de la revolución-, padres -él burócrata y antiguo partidario del general Juan Almazán y ella ama de casa-, cuatro hijos - los dos mayores implicados en el movimiento y otros dos más pequeños todos aún en casa) que vive en el edificio Chihuahua, uno de los inmuebles del complejo que dan sobre la plaza de las Tres Culturas. El dispositivo cinematográfico de la película presenta la peculiaridad de ser una historia cuyo peso narrativo recae en el fuera de campo. Este recurso lo sacó Robles después de haber visto Alien el 8vo pasajero, de Ridley Scott, "porque el miedo viene de un monstruo que nunca ves y pensé que algo así podía funcionar en la película. La represión no se ve, se escucha, funciona gracias a los efectos de audio y a seguir la mirada de los personajes. Al fenómeno fílmico de los fueras de campo" (Ortega y Robles, 2018). La historia está espacialmente confinada a ese departamento y temporalmente al transcurrir del día 2 de octubre, desde la madrugada hasta la del día siguiente y con una única escena exterior, la salida del niño -único sobreviviente de la masacre- a la plaza al momento en que están lavando la sangre del suelo y los soldados vigilando. El sonido es el otro elemento que guía el drama, tanto por ser el vector de la cronología como por ser el tono de las acciones con las grabaciones reales del mitin, los disparos y gritos de horror. La represión recae en las fuerzas de coacción del Estado: el ejército, aunque éste mantiene su reverencia por los rangos de antiguos miembros, y el Batallón Olimpia distinguible por su listón blanco en la mano y ejecutor de los asesinatos dentro del edificio. Toda la historia, afirman y recuerdan los escritores, "fue realidad, no solo vivido personalmente sino por compañeros: Luis Carrión vio cómo echaban los cuerpos en dos camiones del ejército; otro reportero del Excélsior se subió a los tinacos y vio a los del guante blanco. Todo es comprobable del suceso. Poniatowska y González de Alba lo relataron. Aunque los testimonios solo dan cuenta de una sola familia asesinada en su departamento" (Ortega y Robles, 2018). Los escritores trataron de contar una historia fílmica de la verdad 
y optaron, entonces, por hacer que cada espectador se reconstruyera o formara su propia imagen del acontecimiento.

\section{Ausencia de memoria visual}

Julie Amiot comenzó su artículo "La fiction cinématographique contre l'oubli historique" comentando el afiche de la película con una frase reveladora del conflicto de memoria: "elle renvoie clairement aux événements du 2 octobre par les éléments qu'elle présente : n’importe quel Mexicain est en effet capable d'identifier l'immeuble de l'arrière-plan comme l'edificio Chihuahua, dont l'importance est double, à la fois géographique et symbolique"6 (Amiot,

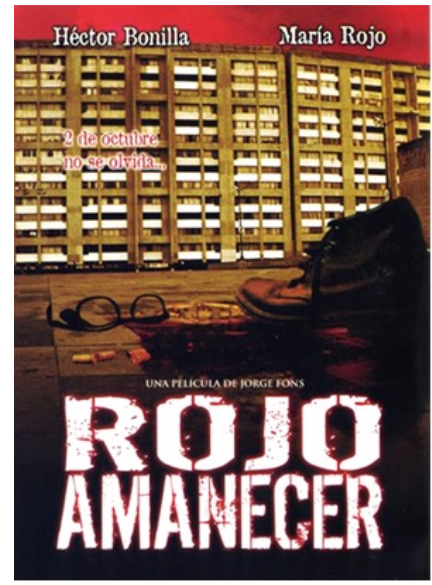

F1. Afiche de Rojo amanecer, 1989 2003, p. 94). En esta tónica de identificación evidente del 68, en el año 2007 una encuesta de Consulta Mitofsky publicó que el movimiento estudiantil de 68 asociado con la matanza del 2 de octubre en Tlatelolco era el tercer acontecimiento histórico mejor conocido del calendario nacional, solo detrás de la Independencia y la Revolución Mexicana (Allier, 2016, p. 20). Sin embargo, esta identificación, al menos en lo visual, puede no ser tan evidente.

Desde la década de 1990 el acontecimiento se convirtió en una bandera política y de lucha a favor de la democracia. La llegada de Vicente Fox a la presidencia de la República en el año 2000 fue un momento de clímax para este discurso, parecía que la democracia estaba triunfando y el movimiento de 1968 volvería a ser tema de análisis y de recuperación de la memoria. En ese sentido, se cedió a la Universidad Nacional Autónoma de México (UNAM) el antiguo edificio de Relaciones Exteriores para que se construyera el Centro Cultural Universitario Tlatelolco (CCUT) con el museo y memorial -entre otros espacios- y fue abierto en el 2007. Sin embargo, volviendo a la noción de ausencia de imagen icónica y vehiculadora de la memoria, su página de internet (http://ccutlatelolco.com/, visita 5 de mayo 2018) no se abre con alguna fotografía, fotograma o pintura. El

\footnotetext{
6 "El afiche nos remite claramente a los acontecimientos del 2 de octubre por los propios elementos ahí presentados: cualquier mexicano es capaz de identificar el inmueble del segundo plano como el edificio Chihuahua, cuya importancia es doble, tanto geográfica como simbólica."
} 
sitio es la presentación de los diversos espacios del CCUT y de la agenda de actividades. Incluso, actualmente el Memorial está cerrado por remodelación y por reorganización para conmemorar el 50 aniversario del movimiento estudiantil.

Pensamos, y esta es la propuesta que quiere problematizar este documento, que el 68 mexicano es un acontecimiento que se mantiene en la memoria histórica por el peso de los discursos políticos y denunciadores, pero sin un soporte visual vehiculador sino más bien como un espectro. Eugenia Allier-Montaño ha realizado un interesante trabajo para clasificar los tonos del discurso y del uso de la memoria en torno al acontecimiento $\mathrm{y}$ su objeto de estudio ha sido mayoritariamente el documento escrito como traficante de emociones y sentimientos del recuerdo y de manifiestos políticos tanto reivindicativos como relativizantes, aunque ha incluido el trabajo de Alberto del Castillo, La fotografía y la construcción de un imaginario (Allier, 2016, pp. 7-25)7. El importante trabajo de Del Castillo sobre la recuperación de los archivos fotográficos y su análisis tiene justamente el objetivo de rastrear la historia de las fotografías, de su manejo en la prensa y de su interpretación cuidando los vicios de la lectura teleológica, y busca por fin último explicar cómo se está formando la memoria del acontecimiento.

El problema aquí es, entonces, el de una imagen vehiculadora ausente no porque no hayan existido, o que hayan existido y enseguida desaparecido por causa de algún tipo de catástrofe, o que existan pero estén todas borrosas e incomprensibles, o simplemente retocadas. Las imágenes existen pero han sufrido una tradición amnésica que las ha bloqueado en su paso rumbo a la memoria colectiva (Zabunyan, 2012, p. 6). Esto no quiere decir que para el público contemporáneo el acontecimiento y la película hayan pasado desapercibidas, al contrario, el film causó un efecto y estuvo concebido no para dar una imagen fiel del acontecimiento sino para crear una memoria personal en el espectador de la represión del 2 de octubre (Amiot, 2003, p. 100). Sucedió el

\footnotetext{
7 Gilberto Guevara Niebla incorpora las sensaciones de la memoria al hablar del mito del 68 mexicano: "La sola mención del Movimiento evoca entre los sesentayocheros imágenes múltiples: despierta un sentimiento de nostalgia, suscita una emoción heroica compartida. El Movimiento es un estereotipo que condensa muchas cosas, fuertes todas ellas: impresiones imborrables en el alma... La memoria, en este caso, está cargada de mitología. Se recuerda al Movimiento con emoción, como algo único, un cuerpo integrado de hechos, exento de contradicciones..." (Guevara, 2001, p. 9).
} 
esquema de transmisión de memoria propuesto por Hirsch: la primera generación, los testigos del evento y sus propios hijos -la segunda generacióncuyo nacimiento fue precedido por los poderosos acontecimientos que fueron a la vez contados intensamente y constituyeron sus propias memorias por efecto de transmisión familiar, tuvieron, además, el peso de recuperar la memoria y lanzar proyectos de mantención ${ }^{8}$. Y finalmente, los hijos de ellos -la tercera generaciónvieron el evento solo por noticias lejanas -o a veces ni las vieron u oyeron- y se han quedado con el eco de un pasado remoto. Esta generación que remite a la ruptura con esta historia, es la censura voluntaria de los padres a los hijos en un afán de protección para evitarles lo mismo que se contaminen de la ideología revoltosa estudiantil como de convertirse en blanco de la represión estatal.

En este sentido, el 2 de octubre de 1968 no ha recibido la misma atención audiovisual que, por ejemplo, la revolución mexicana. Podrían parecer evidentes las razones: uno es un episodio que dura menos de un año y el otro fue una guerra de años que provocó un replanteamiento del Estado mexicano. Robles piensa que de cierta manera este olvido o rezago de mediatización entre uno y otro se debe a la censura, al hostigamiento oficial y a "que los directores del cine son muy culeros y temerosos, son muy zacatones y no querían perder sus privilegios. Aunque ahora hay varios proyectos... pero hay pocos testimonios de la época. En general sobre cualquier acontecimiento contemporáneo" (Ortega y Robles, 2018). Y en efecto, las películas de la revolución mexicana, a excepción de las primeras sonoras de 1930, en específico las de Fernando de Fuentes más ambiguas, fueron afines al discurso oficial. Pero ni siquiera de esas ha tenido el 68, de las que acompañen las diversas versiones oficiales de los acontecimientos.

Ciertamente existen documentales como El Grito (Leobardo López Aretche, 1969) que rescató material visual y registró otro tanto durante las manifestaciones con los estudiantes del (CUEC) 9 y la serie dirigida por Carlos Mendoza (Batallón Olimpia, 1998; Operación Galeana, 2000; y Tlatelolco las claves de la masacre, 2003) con la producción del canal 6 de julio. El trabajo de

\footnotetext{
8 Marianne Hirsch analizó los esquemas de transmisión de memoria, formación de la memoria colectiva y cultural recuperando las propuestas de Jan y Aleida Assmann para plantear su noción de transmisión de la memoria (Hirsch, 2008, pp. 103-111).

9 Para un listado comentado de los documentales producidos en el momento inmediato a la matanza se puede consultar: De la Vega, E. (1999). "Notas sobre el movimiento estudiantilpopular de 1968 en el cine mexicano". Secuencias, Madrid, 10 (julio).
} 
López Aretche es un testimonio en bruto presentado en un montaje de película encontrada y audios reinsertados. Mientras que el trabajo de Mendoza es una investigación e interpretación de la película rescatada y descubierta sobre todo en las pesquisas del material filmado por los reporteros enviados por parte del gobierno. Del lado de la ficción se pueden citar dos películas: Borrar de la memoria (Alfredo Gurrola, 2010) y Tlatelolco, Verano de 68 (Carlos Bolado, 2013). La primera es más un policial y la segunda un romance juvenil interrumpido por las manifestaciones, la matanza y los conflictos clasistas.

A pesar de sus diferencias, los cuatro documentos (cineastas en los documentales y periodistas y fotógrafos en los personajes de las ficciones) comparten la ansiosa búsqueda de la imagen vehiculadora ausente y el conflicto de interpretar las existentes. Todos, tanto ficciones como documentales, insisten en conseguir la prueba del acontecimiento, la evidencia de su existencia e incluso la fotografía o video en prueba absoluta de la realidad. La ficción adquiere el valor de retrato de la realidad y de informador incontestable de los acontecimientos, de ahí la aseveración de Bolado en el sentido de realizar una película que contara lo sucedido durante los meses previos a la matanza, porque de esa "ya existe Rojo Amanecer de Jorge Fons, donde se habla de lo que ocurrió el 2 de octubre de 1968” (Huerta, 2010).

Parecería que ante la ausencia de imágenes vehículos, o mejor dicho, el todavía no descubrimiento o selección de esas imágenes vehiculadoras, al acontecimiento se le niega y esconde también una iconografía sensible (Taccetta y Veliz, 2013, pp. 4-7). Rojo amanecer por su parte renuncia a esa búsqueda, prefiere dejarle al espectador resentir la pulsión escópica y huir al conflicto de cómo recrear el horror. Los audios rescatados e insertados en la cinta para marcar la temporalidad de la manifestación y la represión sirven para convocar al fantasma y acudir a la imaginario colectivo, ya sea melancólico, entusiasta o resignado, y delinear la figuración de la violencia (Errazu, 2018, p. 239). Robles explica esta elección porque preferían no hacer imágenes que pudieran caer en dolo sino en dejar a la imaginación. Pero la imaginación no es inocente ni libre sino que viene a ocupar el lugar de la imagen ausente por amnesia o temor al acontecimiento partiendo de referentes visuales ligados a las guerras y matanzas; el recurso de soportar el relato en el dispositivo del fuera de campo nos obliga a utilizar la 
facultad crítica para discernir entre la multitud de posibilidades de un asesinato y colocar la postal retenida en nuestro álbum de fotografías (Zabunyan, 2012, p. 9). El recurso del fuera de campo de Rojo amanecer lleva al espectador a realizar un análisis teleológico ${ }^{10}$ que no exige siquiera pensar en el dispositivo cinematográfico; más bien, el espectador conocedor del contexto supone e imagina cómo van a terminar los personajes, mientras que un espectador ajeno al evento solo acudirá a referentes más libres de guerra y violencia.

Ninguna de estas películas ha trascendido para convertirse en referentes visuales del acontecimiento. Rojo amanecer y El grito son tan solo -y no es poco- las referencias de la denuncia y vivencia de la represión. Estas películas no tratan de mostrar los hechos tal y cómo fueron "sino bajo la forma de una revisión de nuestro encuentro con ellos desde el presente y, por consiguiente, analizando cómo otros 'presentes' intermedios entre los acontecimientos y nosotros se han enfrentado con ellos y han influido en nuestra visión" (Sánchez-Biosca' 2006, p. 14). En las ficciones mencionadas de los años 2000, cierto peso del problema recae, pensamos, en la intemporalidad de los diálogos. Las películas hablan más a los jóvenes del 2010, son testimonios de su época y los personajes no están anclados, por tanto, en el contexto de 1968. Si Rojo amanecer se preocupó por presentar tres registros de lenguaje representados en las tres generaciones que viven en el departamento, en las otras ficciones los personajes no tienen matices, los únicos tonos temporales los aportan las músicas. Para Robles el valor del dialoguista de cine consiste en hacer que sus personajes se expresen por su lenguaje, vestimenta y, en seguida, por su gestualidad; los diálogos no tienen que ser realistas sino verosímiles (Ortega y Robles, 2018).

Rojo amanecer se encuentra a medio camino generacional, entre los documentales inmediatos del acontecimiento y las ficciones policiales de esta década. La película de Fons goza, para las generaciones de ruptura, del estatuto de ser un documento viejo, con sus páginas “imágenes" amarillas por el paso del tiempo, lo que le otorga el beneficio de ser ya una fuente histórica entre los jóvenes por efecto del engaño de que lo viejo es más verídico. Sin duda que las obras fílmicas de temática histórica siempre están, al mismo tiempo, fijadas en el

10 Para ver en qué consiste el esquema del análisis teleológico se puede consultar: Lindeperg, S. (2008). "Le film palimpseste". In Paisagens: o trabalho do temp, Doc's Kingdom (pp. 146-150). Seminario Internacional sobre Cinema Documental, Portugal. 
presente, pero las ficciones históricas que fueron realizadas en el pasado, obtienen una nueva codificación y se convierten en un doble documento histórico, el de su narración y el de su producción.

Es evidente que las películas reenvían a imágenes de represión, a los granaderos, al ejército y a la policía, pero en México, argumentan Robles y Ortega no hubo un cine comprometido sobre el acontecimiento en el tono del neorrealismo italiano y quizás por eso no hay una imagen vehiculante del suceso del 68. El deber de memoria al recuperar los acontecimientos pasados, además de mantenerlos en la memoria colectiva, debería de tener alguna utilidad o bien estar enfocado al buen uso de la memoria (Todorov, 2015, pp. 25-31) y, en México aún no se le ha encontrado un uso institucional a ese deber de recordar y seleccionar los acontecimientos del 68.

\section{Conclusión}

Plantear un debate en torno a qué y quiénes recuerdan el 68 en México implica tocar un tema de historia presente y viva, siempre susceptible de matices a perfilar y a replantear a causa de las conclusiones generalistas. Señalar que existe una ausencia de imágenes vehiculadoras del acontecimiento con la memoria presente a pesar de que existan las imágenes es proponer que en los canales de transmisión generacional hay barreras y a la vez que no hay dispositivos de recreación iconográfica capaces de trascender los aparatos oficiales y que las expresiones artísticas tampoco tienen aún condensaciones discursivas suficientemente difundidas. Cierto, hay muchos movimientos sociales más en el siglo XX que fueron poco mediados por el cine y la imagen. Quizás los más mediatizados fueron la expropiación petrolera, gracias a la figura carismática de Lázaro Cárdenas, y la nacionalización de la industria eléctrica en 1960, a través de una tímida campaña de apoyo con la película Rosa blanca (Roberto Gavaldón, 1961) que planteaba una suerte de analogía entre ambas expropiaciones; ambos eventos tuvieron el respaldo del Estado. Mientras que las guerrillas de Lucio Cabañas o el Zapatismo -bien que éste gozara de una amplía mediatizaciónfueron finalmente reenviadas a cajones de la marginalidad política. Pero el 68 mexicano es el único que tiene el reconocimiento y conmemoración anual desde las universidades. 
En la introducción de este artículo mencionamos la creación de memorias mediatizadas por un efecto de transtextualidad como la sucedida con la Shoah, ahora podemos pensar que no existe migración de imágenes de un soporte a otro (no sólo visual sino también discursivo) y que por encadenamiento creen archivos para el 68 mexicano. Existen, pues, imágenes testigos del evento pero no vehiculadoras con la memoria presente. Éstas se pueden encontrar, sin embargo, en la ficción que viene a ocupar la función de moldeadora de memorias (SánchezBiosca, 2011, pp. 31-36). Rojo amanecer es, por tanto, un hito en la historia cinematográfica mexicana y en la construcción del acontecimiento "Tlatelolco 2 de octubre”. Es la única cinta que, paradójicamente, ha asentado imágenes del acontecimiento a partir de los rostros de los actores de la ficción.

Han pasado dos generaciones desde el acontecimiento y la actual ha nacido posterior a la exhibición y difusión de la película. La película de Pons se ubica en un punto intermedio de generaciones, de las contemporáneas al evento y de sus nietos, y puede remitir a las generaciones a identificar los acontecimientos y a los personajes en una suerte de presencia espectral que debe lidiar con lo que Errazu llama "identificación afectiva con un legado militante... [y] reapropiación de procedimientos críticos”, pero sin consolidar aún una construcción hegemónica sino dejando en evidencia la ilegibilidad de los restos del archivo. (Errazu, 2018, pp. 240 y 244). Si la cinta requería estar -para ser entendida- inmersa en un contexto específico y con un espectador despierto a ciertos códigos cinematográficos, las proyecciones actuales pondrían a prueba la vigencia de la memoria visual. Al momento de la conclusión de este documento la película Roma de Alfonso Cuarón ha ganado el León de Oro en el 75 Festival de Cine de Venecia, y Nicolás Echeverría se ocupa de la curación de videos e imágenes que se proyectarán en el Memorial de Tlatelolco en octubre. La mediatización de ambos eventos en el marco de la conmemoración de los 50 años podría ayudar a proponer otras imágenes, aunque quizás, como está sucediendo, no en un discursiva localizada en un acontecimiento, sino en las historias de las represiones estudiantiles de los últimos 50 años atisbadas por los 43 estudiantes de Ayotzinapa. 


\section{Referencias bibliográficas}

Allier-Montaño, E. (2016). Memory and History of Mexico '68. European Review of Latin American and Caribbean Studies. Revista Europea de Estudios Latinoamericanos y del Caribe, 102 (october), 7-25.

Amiot, J. (2003). La fiction cinématographique contre l'oubli historique. Rojo Amanecer de Jorge Fons, (Mexique, 1989). En Image et mémoire (pp. 109120). Lyon : GRIMH/GRIMIA, Collection des Cahiers du GRIMH.

Bratu Hansen, M. (1996). Schindler's List Is Not Shoah: The Second Commandment, Popular Modernism, and Public Memory. Critical Inquiry, 22 (winter).

Cerón, A. (2012). El Movimiento del 68 en México interpretaciones historiográficas 1998-2008. Andamios, 9 (20), 237-257.

Comolli,J-L. (2008). Images d'archives : emboîtement des regards -Entretien avec Sylvie Lindeperg. In Paisagens: o trabalho do temp, Doc's Kingdom (pp. 151-156). Portugal: Seminario Internacional sobre Cinema Documental.

De la Vega, E. (1999). Notas sobre el movimiento estudiantil-popular de 1968 en el cine mexicano. Secuencias, Madrid, 10 (julio), 66-81.

Del Castillo, A. (2012). Ensayo sobre el movimiento estudiantil de 1968. La fotografía y la construcción de un imaginario. México: Universidad Nacional Autónoma de México-Instituto de Investigaciones sobre la Universidad y la Educación/Instituto Mora, 331 pp.

Ebbrecht-Hartmann, T. (2015). Preserving Memory or Fabricating the Past? How Films Constitute Cinematic Archives of the Holocaust, in Cati, A. and Sanchez-Biosca, V. (eds.), "Archives in Human Pain. Circulation, Persistence, Migration”, Cinéma \& Cie. International Film Studies Journal, XV (24), pp.33-47.

Errazu, M. (2018). No podemos hablar ya sino a través de los restos: fragmento y fantasma del 68 mexicano en el cine experimental contemporáneo, Fotocinema Revista Científica de Cine y Fotografia, 17.

Guevara Niebla, G. (2001). 1968: política y mito. En Enrique Florescano (coord.) Mitos mexicanos (pp. 99-107). México: Taurus.

Hirsch, M. (2008), The Generation of Postmemory. Poetics Today, 29 (1), 103128.

Huerta, C. (2010, enero 11). 1968 que no se olvide, por favor, El Universal.

Jurado, D. (2017). Catastrophe et récit. La représentation littéraire et cinématographique du " terrorisme d'État » en Argentine, au Chili et au Mexique. Paris, Francia : Tesis Doctoral, Université Sorbonne.

Lindeperg, S. (2008). Le film palimpseste. In Paisagens: o trabalho do temp, Doc's Kingdom (pp. 146-150). Portugal: Seminario Internacional sobre Cinema Documental.

Robles, X. y Ortega, G. (1995). Rojo amanecer. México: Ediciones Milagro. 
Robles, X. y Ortega, G. (2018). Entrevista con los escritores de Rojo amanecer, 12 de enero.

Rojo, J.J. (2010). La memoria como espectro en Rojo amanecer de Jorge Fons. Arizona Journal of Hispanic Cultural Studies, 14, 49-64.

Sánchez-Biosca, V. (2006). Cine de historia, cine de memoria. La representación y sus límites. Madrid: Cátedra.

Sanchez-Biosca, V. (2011). Migration d'images et icônes de la mémoire ; l'apport de la guerre d'Espagne. En J.P. Bertin-Maghit (dir.), Lorsque Clio s'empare du documentaire. Vol. II, Archive, témoignage, mémoire (pp. 31-43). France : Ina-L'Harmattan.

Taccetta, N. y Veliz, M. (2013). Escrituras cinematográficas de la historia. Entrevista con Sylvie Lindeperg, La fuga, 15, 1-11.

Todorov, T. (2015). Les abus de la mémoire. France: Arléa.

Vázquez Mantecón, A. (1998). No se olvida... rojo amanecer. Estudios Interdisciplinarios de América Latina y el Caribe, 9 (1), 141-144.

Velazco, S. (2005). Rojo amanecer y La ley de Herodes, cine político de la transición mexicana. Hispanic research journal, 6 (1), 67-80.

Zabunyan, D. (2012). Les images manquantes, Carnets du Bal, 3. 4-10.

\section{Películas citadas}

Bolado, Carlos (2013). Tlatelolco, Verano de 68. México: FIDECINE, Producciones Corazón, Maíz Producciones.

Fons, Jorge (1989). Rojo Amanecer. México: Cinematográfica Sol, Valentín Trujillo y Héctor Bonilla.

Gurrola, Alfredo (2010). Borrar de la memoria. México: Magenta Films, Sula Films

López Aretche, Leobardo (1969). El grito. México: CUEC. 